\title{
CONTROLLING OBOR PROJECTS' RISKS BY APPLYING MODERN PROJECT MANAGEMENT TOOLS
}

\section{Miljan Radunović}

PhD candidate, Singidunum University, Belgrade, Serbia

\begin{abstract}
:
One Belt One Road (OBOR) Initiative launched by People's Republic of China is currently the biggest publicly undertaken investment portfolio in the world. It refers to construction of numerous capital infrastructure projects in Europe and Asia, accompanied by upgrading naval and continental transportation roots. Megaprojects carry significant amount of various risks on its own. Mutually dependent megaprojects, relying on one sole credit loan provider targeting a number of diversified developing countries eager to attract foreign investments with affordable interest rates, increase the scope and effect of the investing risks. Modern industrial and institutional project management tools have considerably contributed to the third and fourth industrial revolution, resulting in significant industrial, commercial and economic development of markets in Europe and United States of America. Applying these project management tools can result in risk control of future OBOR projects and ensure that all stakeholders benefit from future development and expansion of OBOR.
\end{abstract}

Keywords:

China, Investments, OBOR, Project Management Tools, Risk Control

\section{INTRODUCTION}

One Belt One Road (OBOR) Initiative, also known as Belt and Road Initiative (BRI), or the New Silk Road project, was announced in September 2013 in Astana (Kazakhstan) by the president of People's Republic of China, Mr. Xi Jinping. It refers to the initiative of China leading a massive investment portfolio, envisaging capital infrastructure projects located throughout central, southern and western Asia, Africa, Middle East and Europe. Project scope focuses on construction of road and naval transportation infrastructure such as highways, railroads and ports, along with capital energy, gas and oil facilities infrastructure. Overall goal of OBOR is for China to lead the integration of this market, contributing to its sustainable economic and trading development in the $21^{\text {st }}$ century. So far OBOR Initiative has attracted considerable attention in global business market inspiring different comments and opinions. Nevertheless, OBOR Initiative remains at the moment the largest investment initiative led by one country in perspective of financial magnitude, target market area and scope of work. As such it can be compared to the Marshal's Plan (Shen \& Chan, 2018). A number of state-governed supporting mechanisms for OBOR Initiative have been established, with the most prominent being Foreign Aid and Government-Sponsored Investment Activities (FAGIA), Bank (AIIB). OBOR Initiative map is presented in Figure 1. 
Figure 1. Map of OBOR Initiative

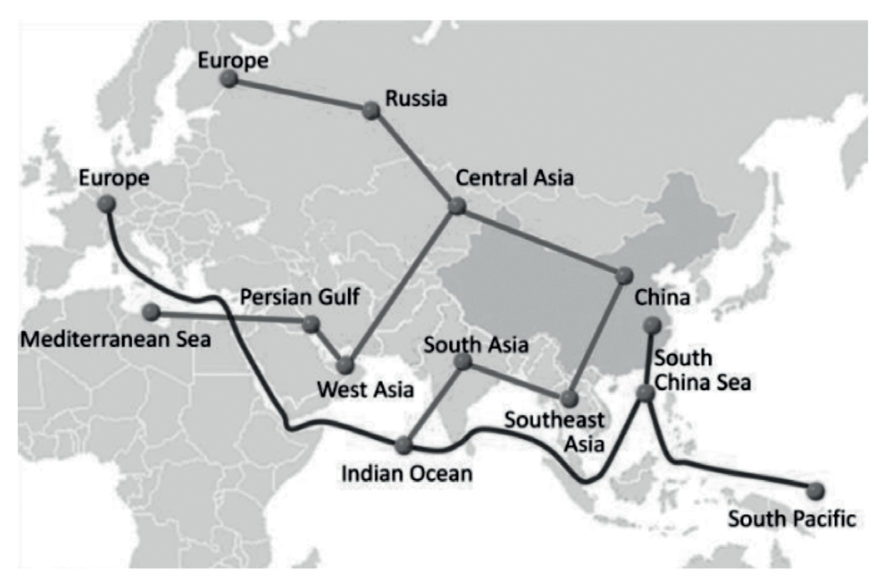

Source: Legislative council of Hong Kong

Logical Framework Approach (LFA), in some cases referred to as LogFrame, is a tool used for project planning, monitoring and evaluating, initially developed in 1970s upon request of the United States Association for International Development (USAID), as a comprehensive tool for evaluating effectiveness and efficiency of international aid and support projects funded by USAID (Schmidt T, 2009). Logical Framework Matrix (LFM) is an output document of LFA which consists of a four by four matrix. LFM contains most important information on the project, differentiated in four columns - Narrative Summary, Objectively Verifiable Indicators, Means of Verification and Assumptions, which are intersected by four rows - Overall objective, Specific Objective, Expected Results and Activities. An example of the LFM is presented in Figure 2.

Figure 2. Logical Framework Matrix (LFM)

\begin{tabular}{|l|c|c|c|}
\hline \multicolumn{1}{|c|}{$\begin{array}{c}\text { NARRATIVE } \\
\text { SUMMARY }\end{array}$} & $\begin{array}{c}\text { OBIECTIVEIY } \\
\text { VERIFABLE } \\
\text { INDICATORS }\end{array}$ & $\begin{array}{c}\text { MEANS OF } \\
\text { VERIFICATION }\end{array}$ & ASSUMPTIONS \\
\hline Overall objective & & & \\
\hline Specific objectives & & & \\
\hline Expected results & & & \\
\hline Activities & & & \\
& & & \\
& & & \\
& Means: & Costs: & \\
\hline
\end{tabular}

Key stronghold of LFA with LFM is the ability to easily describe project outcomes in concise quantitative and qualitative manner. This is the result of processing data collected and interlinking all of information acquired through usage of the intervention logics applied in LFM design phase. LFM has three intervention logics applied in itself. First - vertical intervention logic, which is applied in the first column on the left (Figure 2). Here the systems approach is applied using causal interlinking which relies on the "if - then" conclusions. It states that if work listed in the field "Activities" is successfully fulfilled, this will result in accomplishment of milestones listed in "Expected results" field. The successful completion of work listed in "Expected results" leads to accomplishment of milestones listed in "Specific objectives" and, likewise, this leads to successful accomplishment of items listed in "Overall objective". Vertical intervention logic is presented in Figure 3.

Figure 3. LFM Vertical intervention logic

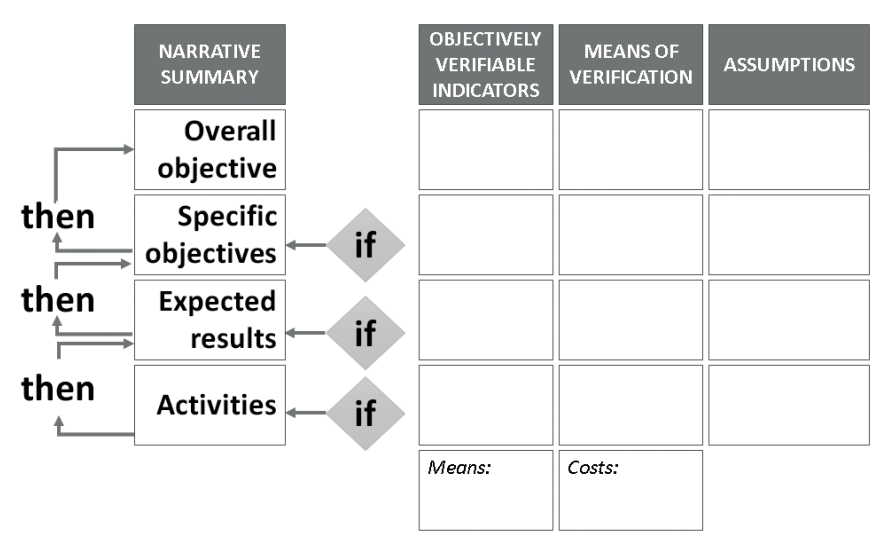

Second - horizontal, intervention logic ensures reliability of results and accounts for quality assurance and control. In this case, results from any of the fields within the first column are confirmed by being compared against Objectively Verifiable Indicators (OVI) using Means of Verification (MOV). Horizontal intervention logic is presented in Figure 4.

Figure 4. LFM horizontal logic

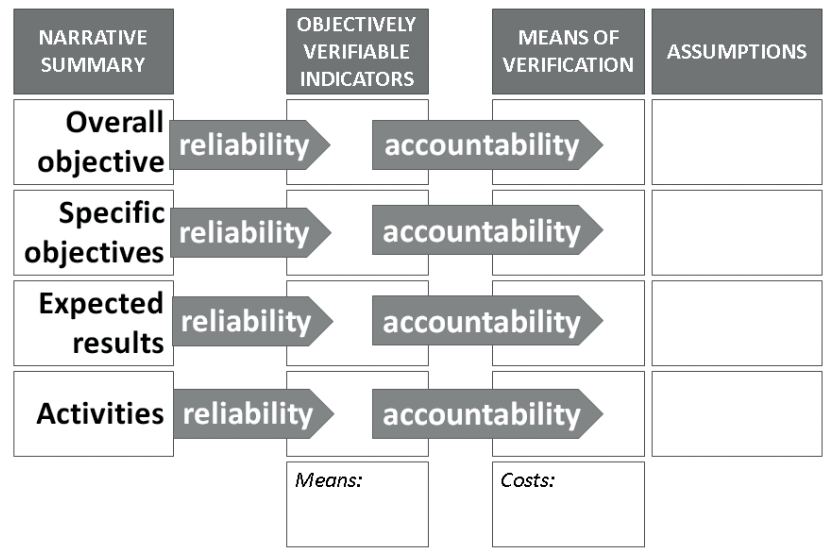

Third intervention logic applied in the LFM is referred to as cross-check intervention logic. It account for both 
vertical and horizontal intervention logic, but now includes the last column entitled "Assumptions". This column contains information on occurrences, factors and other risk sources that come from outside of the project scope and environment, and can contribute or endanger the overall sustainability of the project. This intervention logic follows the "if - and - then" conclusion, which has the following conclusion order

- if [Activity] and [Assumption(s)] then [Expected Result(s)]

which is repeated on the next upper level, analogically as:

- if [Expected Result(s)] and [Assumption(s)] then [Specific Objective(s)]

and is accordingly followed by linking with the Overall Objective in the following way:

- if [Specific Objective(s)] and [Assumption(s)] then [Overall Objective]

Cross-check intervention logic is presented in Figure 5.

Figure 5. LFM cross-section intervention logic

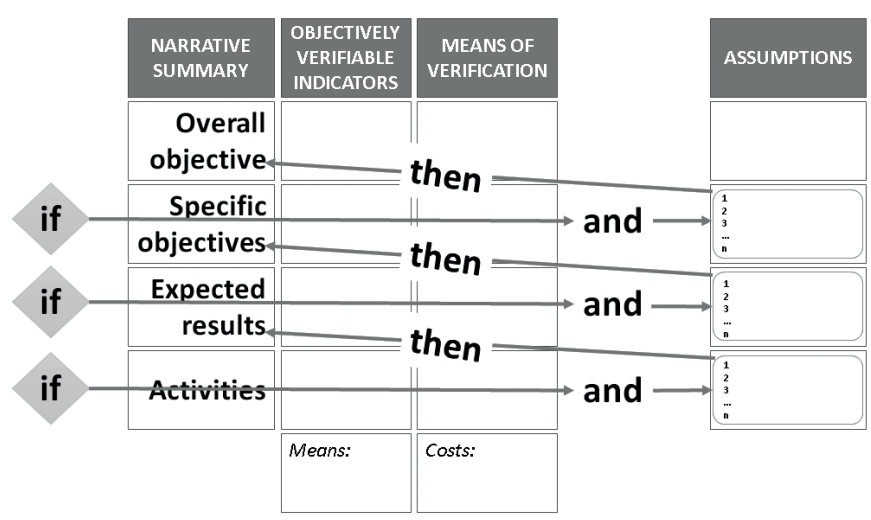

\section{LITERATURE REVIEW}

\section{Megaprojects}

Megaproject can be considered a project that features a large investment commitment, accompanied by vast complexity in management terms, and a long term impact on the environment it is developed in (Brookes \& Locatelli, 2015). From the managing perspective, megaprojects require complex and cross sector engagement for the purpose of successful coordination and completion, accounting for technical, financial, social and other relevant resources $(\mathrm{Hu}, \mathrm{Chan}, \mathrm{Le}, \&$ Jin, 2013; Locatelli, Mancini, \& Romano, 2014). Over the course of history megaprojects naturally evolved which led to both theoretical and practical sophistication of their interpreting. Three traditional success indicators - cost, time and quality (Locatelli et al.), often referred to as "iron triangle", are facing constant questioning and reconsidering, in the light of the complexity of project being developed today and planned for the future, as they are often referred to as short-termed and interpreted as contract-based.

Following the analysis of 318 industrial megaprojects from different environments, Merrow (2011) shows that up to $65 \%$ of megaprojects are considered a failure. This is why a huge scope of study is open for the application of risk prevention tools in megaprojects, as presented in Kardes et al. (2013). Reliable literature offers a number of theoretical perspectives on this issue, out of which three are considered most prominent. First one is the complexity theory, which is promoted by various authors (e.g., Geraldi, Maylor, \& Williams, 2011; Pich, Loch, \& De Meyer, 2002; Howell, Windahl, \& Seidel, 2010; Shenhar \& Dvir, 2007), suggesting ways of assessing complexity in projects and offering methods for studying the complexity itself and its impact. Second is the structural theory (Pennings, 1992). It promotes "one size doesn't fit all" approach and intends to identify differences among megaprojects by using different criteria and dimensions, suggesting ways to successfully account for diverse kinds of megaprojects. Third theory is the transaction cost economics one (Douma \& Schreuder, 2008; Luzzini, Caniato, Ronchi, \& Spina, 2012), which observes projects as value creation processes, which is of use when analyzing the net worth of benefits versus investments. Flyvbjerg (2017) defines Political, Technological, Economical, and Aesthetic as the "four sublimes" that drive project management, with their appropriate characteristics. Also precise and descriptive approach to risks and challenges in infrastructure megaprojects is available from Van de Graaf and Sovacool (2014) and Sovacool and Cooper (2013).

\section{China's recent economic development overview}

People's Republic of China was founded in 1949 with governing political party being the Chinese Communist Party (CCP), which has been in power since 1940s. Following the death of CCP Chairman Mr. Mao Zedong in 1976, changes introduced and implemented by his successor Mr. Deng Xiaoping (1904 - 1997) are considered to be key turning points in Chinese economy and overall industrial development. Major change in political philosophy that came with Mr. Deng Xiaoping, was introducing the approach that peaceful times are best to engage in economic progress and development, compared to the approach of Mr. Mao Zedong who advocated that chaos leads to changes. At the moment of Mr. Deng Xiaoping stepping into power, China's population was 930.7 million (WBG) and gross domestic product (GDP) growth equaled -1.6 (OECD). 
"Going Out" (Zou Chuqu) policy proved to be crucial in the process of China's economic transition. It revolves around the idea of China exporting goods, raw products, commodities, along with capital intended for direct investments with the goal of establishing a lasting and interdependent relation with foreign markets (Ministry of Commerce). With this in mind, in late 1980s Mr. Deng Xiaoping laid down foundations of the foreign policy reforms often referred to as the "24 Character Strategy". By mid 1990s, all predefined performance indicators have been fulfilled, meaning that in accordance with the " 24 Character Strategy" the milestone named "Moderately prosperous society" (Xiaokang) has been achieved. In 1997, new performance indicators have been established in order to reach the new milestone by 2020 , marking the centenary of establishing the CCP. This all is leads to the supreme goal of reaching the "Overall prosperous society" (Quianmian Xiaokang) due on 2050, marking the centenary of People's Republic of China.

China has valued its relationship with the EU very much and oriented itself towards intensifying their cooperation in numerous of fields. This is why Chinese's officials' approach to the EU has been pragmatic from the start. EU on the other hand welcomed the initiative and fostered intensive diplomatic and trade building relations. Once initiated, this cooperation took a high pace. In 1975, the first diplomatic relations have been established. By 1978 the first official document - "1978 Trade Agreement" was signed, followed by "Sino-EU Trade and Economic Cooperation Agreement", signed in 1985. A major setback in China - EU relations has occurred as a result of a political crisis in Beijing, related to political protests in the Tiananmen Square in 1989. In upcoming years China retained its rights over Hong Kong (in 1997) and Macau (in 1999). The next important step would be China entering the World Trade Organization (WTO) in 2001. At that time, China, led by Mr. Hu Jintao as President, introduced and promoted the idea of a "peaceful rise" which implied that its economic progress is defined as nation's legitimate goal, for which global peace is a crucial prerequisite. The September 2008 financial crisis in USA, had no significant effect on China, since in 2009 China reached $8.7 \%$ of its national economic growth. Figure 6 depicts parallel tracking of aforementioned key political developments of China and the EU in line with the rise of China's gross domestic product (GDP).

Figure 6. China's GDP in line with global developments

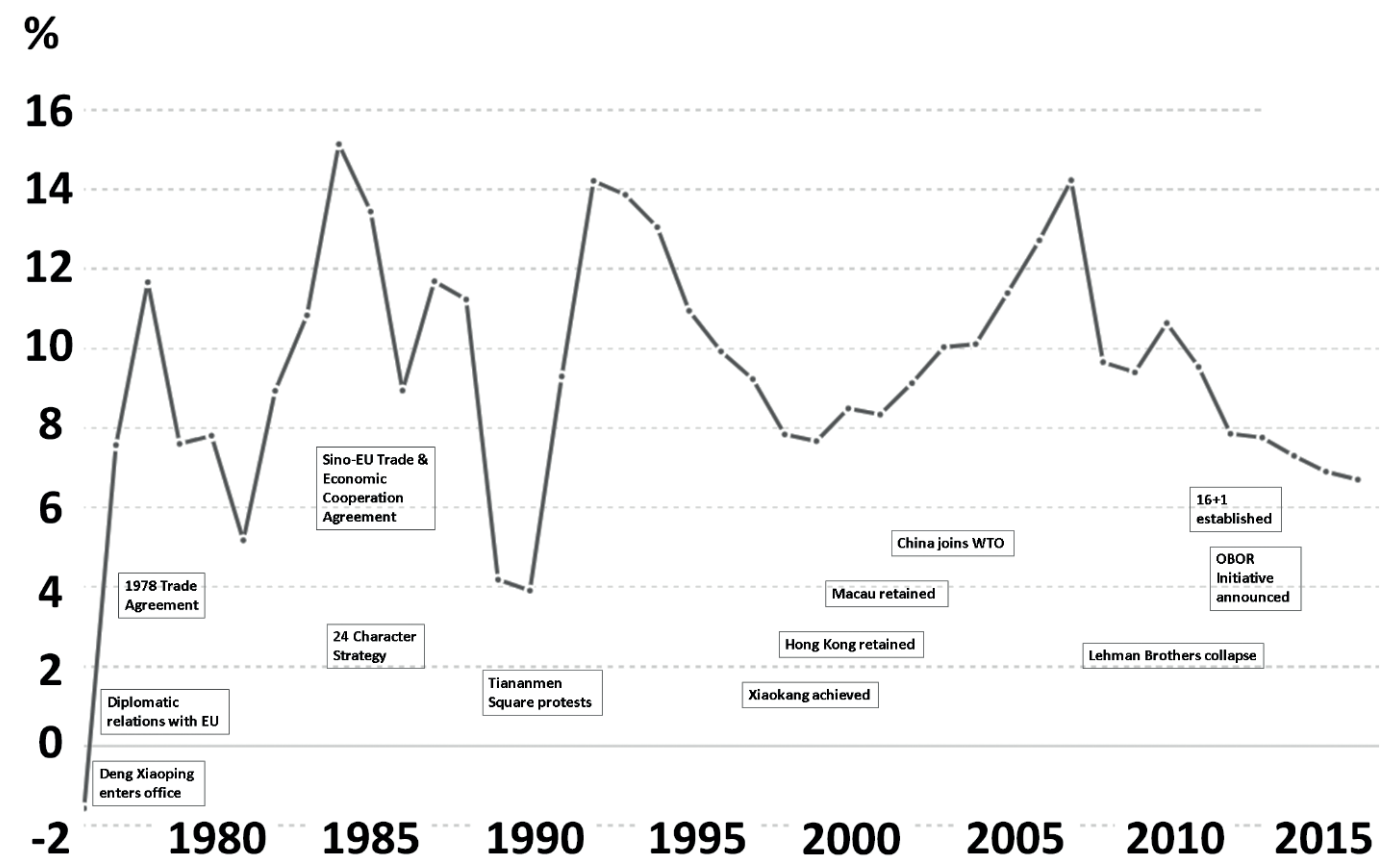

\section{METHODOLOGY}

Research methodology applied in the paper is an in- similarly constructed cases and uses a structured process to review cases in order to reach "cross-case" patterns. These "patterns" are then applied to generate theoretical propositions. This approach is based on the seminar 
work of Kathleen Eisenhardt (1989). She had derived a process where theoretical generalizations can be generated from reviewing a set of cases of a particular phenomenon observed. Eisenhardt (1989, p.545) also discusses the issue of "reaching closure", referring to "when to stop adding cases, and when to stop iterating between theory and data". In her opinion, researchers are advised to conclude adding cases once reaching theoretical saturation and/or once the incremental improvement to quality is minimal. The main objective of this paper is to understand how application of LFA with LFM in OBOR Initiative related megaprojects can be applied to control their risks, and ensure efficient management of megaprojects within $\mathrm{Eu}-$ ropean market.

\section{RESULTS AND DISCUSSION}

\section{China-CEEC meeting}

In 2012, Poland hosted the first annual meeting of the "China and Central and Eastern European Countries" platform, often referred to as "China-CEEC meeting", or " $16+1$ " framework. Meeting gathered heads of states from countries in Central and Eastern Europe, together with highest representatives of China, discussing investment projects China intends to fund in these countries. Member countries of $16+1$ framework, along their official population in 2017 and the EU membership status are presented in Figure 7.

Figure 7. 16+1 Member countries with their population and the EU status

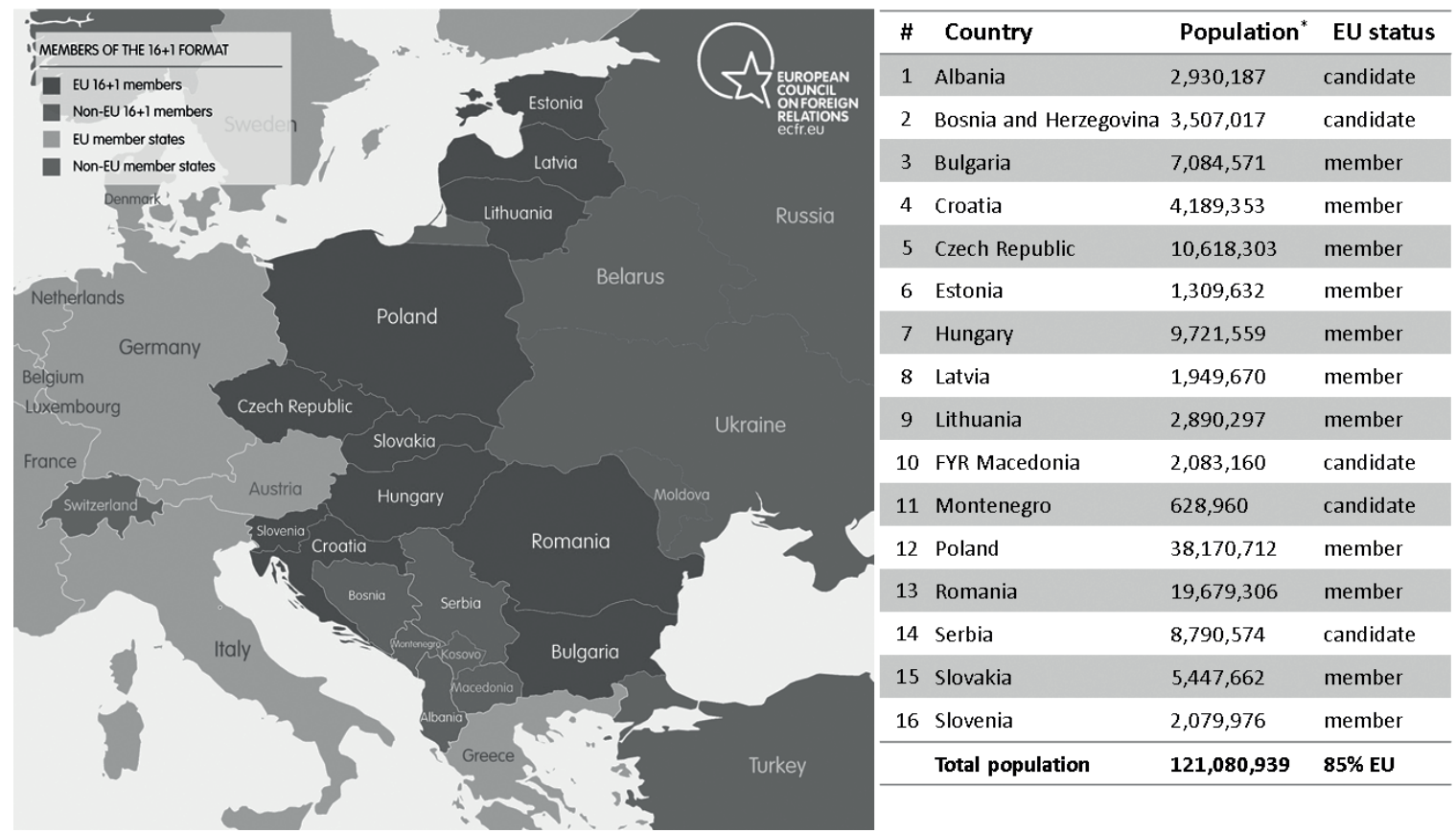

During the following $16+1$ meetings (2013 in Romania, 2014 in Serbia, 2015 in China, 2016 in Latvia, 2017 in Hungary and 2018 in Bulgaria), a number of joint documents was signed and promoted, for specific projects to be implemented in the upcoming period. Globally, the $16+1$ meetings give the public an annual outlook of China's trends intentions, also being an efficiency indicator of its
European market expansion. The illiquidity of credit takers however remains the biggest sustainability threat, and can be easily indicated by comparing the value of contracted megaprojects to each country's annual gross domestic product (GDP). Figure 8 shows most prominent megaprojects announced on previous $16+1$ meetings, with their value and percentage of the country's annual GDP. 
Figure 8. Prominent CEEC projects announced on previous $16+1$ meeting

\begin{tabular}{|c|c|c|c|c|}
\hline \# & Country & Project & $\begin{array}{l}\text { Value } \\
\text { [MEUR] }\end{array}$ & $\begin{array}{l}\% \text { of } \\
\text { GDP }\end{array}$ \\
\hline 1 & Albania & $\begin{array}{l}\text { European Motorway VIII: Arber motorway } \\
\text { to FYRoM }\end{array}$ & 200 & 2 \\
\hline 2 & \multirow{4}{*}{$\begin{array}{l}\text { Bosnia and } \\
\text { Herzegovina }\end{array}$} & Banja Luka - Split motorway & 600 & \multirow{4}{*}{16} \\
\hline 3 & & $450 \mathrm{MW}$ unit at Tuzla thermal power plant & 786 & \\
\hline 4 & & 350 MW Banovići thermal power plant & 400 & \\
\hline 5 & & $300 \mathrm{MW}$ Stanari thermal power plant & 350 & \\
\hline 6 & Hungary & Belgrade-Budapest high-speed railway link & 1500 & 1 \\
\hline 7 & \multirow[t]{2}{*}{ Montenegro } & Section of the European motorway XI & 809 & \multirow{2}{*}{27} \\
\hline 8 & & Renewal of the ship fleet & 100 & \\
\hline 9 & \multirow[t]{4}{*}{ Romania } & $\begin{array}{l}500 \mathrm{MW} \text { unit at Rovinari thermal power } \\
\text { plant }\end{array}$ & 1000 & \multirow{4}{*}{4} \\
\hline 10 & & $\begin{array}{l}\text { Mintia-Deva thermal power plant } \\
\text { modernization }\end{array}$ & 250 & \\
\hline 11 & & $\begin{array}{l}\text { Tarnita-Lapustesti hydro power plant } \\
\text { expansion }\end{array}$ & 1000 & \\
\hline 12 & & $\begin{array}{l}\text { Units } 3 \text { and } 4 \text { at Cernavoda nuclear power } \\
\text { plant }\end{array}$ & 2000 & \\
\hline 13 & \multirow[t]{5}{*}{ Serbia } & Danube bridge & 170 & \multirow{5}{*}{8} \\
\hline 14 & & Kostolac Phase I & 130.5 & \\
\hline 15 & & $\begin{array}{l}350 \mathrm{MW} \text { unit at the Kostolac thermal power } \\
\text { plant }\end{array}$ & 700 & \\
\hline 16 & & Belgrade-Budapest high-speed railway link & $\begin{array}{c}800 \text { (in Serbia, } \\
\text { out of } 1500 \text { ) }\end{array}$ & \\
\hline 17 & & $\begin{array}{l}\text { Sections of the European motorway XI (to } \\
\text { Montenegro) }\end{array}$ & 900 & \\
\hline 18 & FYRoM & Motorways construction & 580 & 7 \\
\hline
\end{tabular}

Source: European Bank for Reconstruction and Development (2016), based on Intellinews, 2016 with additional research by author based on various media reports

Risks of OBOR Initiative related megaprojects in European market

Risks are inevitable to any project, hence they are inevitable for megaprojects encompassed by OBOR Initiative. With regards to key parameters that constitute a project, the risks discussed focus on quality and cost issues.

In terms of cost risks, the one concerning nonperforming loans (NPL) is the most important one. In cases of projects announced in the $16+1$ framework (Figure 7), most of the credit beneficiaries are states or state dependent enterprises, which brings considerable risk to general performing of credit repayment. It is possible for a state to sign a credit loan for the purpose of developing a project within the OBOR Initiative and later not be able to perform on the credit, thus not being able to payback the invested money, which results in credit default. The state's authorities can enter negotiations aware that the credit loan might not be paid back in the designated period, all for deliberate purpose of scoring locally on home political grounds. In this case Chinese side is faced with losing the money invested in the project, or compensating it with acquisition of assets, which in cases of megaprojects, can include land and natural resources, such as the recent case of Hambantota port in Sri Lanka. It is however questionable whether and to what extent outcomes like this meet approval of financial authorities that initially provided the credit loan, and of Chinese government authorities. The wider context of the project's failure would also suffer as the expected result (as defined in LFM) has not been accomplished, thus slowing down the overall goal of Chinese investments. Turning to the state that cannot payback the credit loan, the increased public debt and especially acquisition of assets can be a major obstacle to the EU accession process. In terms of low quality performance, it is here that we face the lack of knowledge, experience and skills of Chinese subcontractors, necessary to achieve high level standards required by the EU market. This is a result of Chinese companies gathering considerable experience in infrastructure megaprojects in markets of Africa and Latin America, where they were not subjected to such rigorous performance and quality related criteria by the hosting legal framework and regulations, as is the case in European markets. Examples megaprojects not related to China listed in Figure 8 as well as the ones of the 2009 A2 highway construction failure in Poland, and existing construction delays in the Belgrade - Budapest high speed railroad serve as a reminder of this and a valuable "lessons learned" resource. 
Figure 9. List of famous megaprojects with cost overruns and construction duration details

\begin{tabular}{|l|l|l|l|l|}
\hline$\#$ & $\begin{array}{l}\text { Project name } \\
\text { and country of origin }\end{array}$ & $\begin{array}{l}\text { Start and } \\
\text { completion date }\end{array}$ & $\begin{array}{l}\text { Construction } \\
\text { duration [years] }\end{array}$ & $\begin{array}{l}\text { Cost overrun } \\
{[\text { [ ] }}\end{array}$ \\
\hline $\mathbf{1}$ & Suez Canal, Egypt & $1859-1869$ & 10 & 1,900 \\
\hline $\mathbf{2}$ & Scottish Parliament Building, UK & $1999-2004$ & 5 & 1,600 \\
\hline $\mathbf{3}$ & Sydney Opera House, Australia & $1959-1973$ & 16 & 1,400 \\
\hline $\mathbf{4}$ & Furka base tunnel, Switzerland & $1976-1982$ & 16 & 300 \\
\hline $\mathbf{5}$ & Verrazano Narrow bridge, USA & $1959-1969$ & 10 & 280 \\
\hline $\mathbf{6}$ & Boston's Big Dig artery/tunnel project, USA & $1991-2007$ & 6 & 220 \\
\hline $\mathbf{7}$ & Denver international airport, USA & $1989-1995$ & 6 & 200 \\
\hline $\mathbf{8}$ & Panama canal, Panama & $1881-1914$ & 33 & 200 \\
\hline $\mathbf{9}$ & Minneapolis Hiawatha light rail line, USA & $2001-2004$ & 3 & 190 \\
\hline $\mathbf{1 0}$ & Humber bridge, UK & $1972-1981$ & 9 & 180 \\
\hline $\mathbf{1 1}$ & Dublin Port tunnel, Ireland & $2001-2007$ & 6 & 160 \\
\hline $\mathbf{1 2}$ & Montreal metro Laval extension, Canada & $1962-1966$ & 4 & 160 \\
\hline $\mathbf{1 3}$ & Copenhagen metro, Denmark & $1996-2002$ & 6 & 150 \\
\hline $\mathbf{1 4}$ & Great Belt rail tunnel, Denmark & $1991-1998$ & 7 & 120 \\
\hline $\mathbf{1 5}$ & London Limehouse road tunnel, UK & $1989-1993$ & 4 & 110 \\
\hline $\mathbf{1 6}$ & Brooklyn bridge, USA & $1869-1883$ & 17 & 100 \\
\hline $\mathbf{1 7}$ & Channel tunnel, UK \& France & $1988-1994$ & 6 & 80 \\
\hline $\mathbf{1 8}$ & Karlsruhe-Bretten light rail, Germany & $1989-1992$ & 3 & 80 \\
\hline $\mathbf{1 9}$ & London Jubilee Line extension, UK & $1993-1999$ & 4 & 80 \\
\hline $\mathbf{2 0}$ & Bangkok metro, Thailand & $1996-2004$ & 8 & 70 \\
\hline $\mathbf{2 1}$ & High-speed Rail Line South, The Netherlands & $1998-2009$ & 9 & 60 \\
\hline Source: Bent Flyvbjerg, 2017, "Introduction: The Iron Law of Megaproject Management, in Bent \\
Flyvbjerg, ed., The Oxford Handbook of Megaproject Management (Oxford: Oxford University Press), \\
Chapter 1, pp. 1-18; & & & \\
\hline
\end{tabular}

Given the complexity of OBOR Initiative it is shortsighted to interpret China and the European market as a trivial "sponsor - client" relationship. Reasoning behind this is due to both complexity of scope (cost related) and duration (time related) feature of OBOR Initiative. This simplified interpretation leaves a lot of blind spots for sustainability risks that might occur in the development and implementation of OBOR Initiative. It is why the relation between China and European market is better to be interpreted as a partnering one, especially since both sides have declared this as the key feature of their cooperation, through the last decades of mutual cooperation (Farnell J., Crookes P.I., 2016). With European market and China perceived as partners in OBOR Initiative, LFM is a grateful planning, monitoring and evaluation tool. The applicability increases knowing that overall success of OBOR Initiative is a common goal of both sides. Interpreting OBOR Initiative through LFM is a useful sustainability assessment tool, as it accounts for the context of China's general national policy of economic development. Using the systems approach (Marković D.S, 2012) and relying on the cause and effect conclusiveness of the intervention logics within the LFM, clear correlation between China's national strategies and means of achieving them can be outlined. Accounting for aforementioned national strategies and milestones of Xiaokang and Quianmian Xiaokang presents the Overall objective resulting from fulfillment of Specific objectives. The way Specific objectives are linked to and dependent of Expected results is likewise plausible. As for reassurance, Objectively Verifiable Indicators (OVI) and Means of Verification (MoV) transparently confirm the appropriateness of placing the Chinese national development policy in the Overall objective field of the LFM, as well as effectiveness and efficiency of Chinese national policies' implementation. Figure 10 depicts the aforementioned approach.

Figure 10. OBOR Initiative in LFM

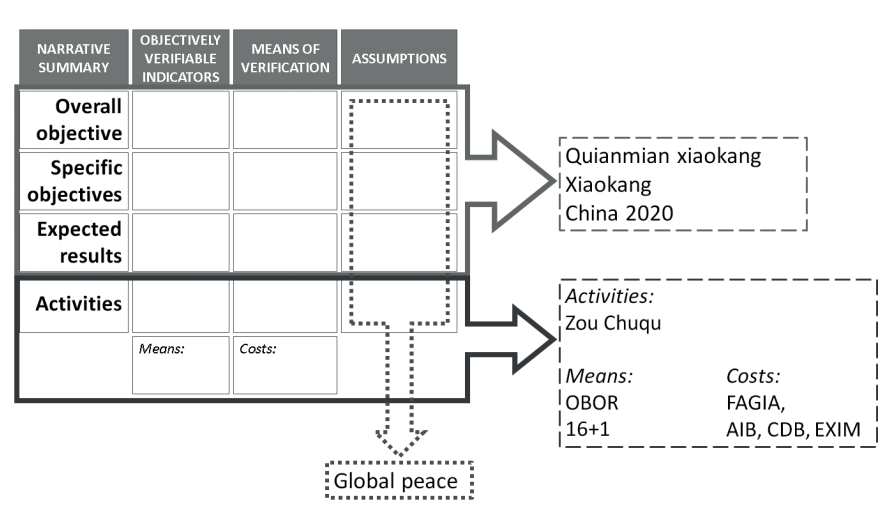

Assumptions are the one field that cannot be controlled by China, as by definition Assumptions in LFM (Schmidt T., 2019) are external risks not controlled by a project manager. This finally brings us to the Activities row, with accompanying Means and Costs, which are most visible to the majority of the public. It is here where OBOR Initiative, 
"China-CEEC meeting" (or " $16+1$ " framework) and their accompanying megaprojects find their place. They are simply a way to achieve a set of activities ("Go Out", or Zou Chuqu). This is why it is incorrect and nothing more than superficial to interpret the OBOR Initiative through the prism of exporting commodities and low wage workers, for the purpose of developing megaprojects. Looking at Figure 8, it is understandable why CEES countries welcome Chinese megaprojects' credit loans. Short term planning and appealing credit loans are too attractive to look ahead and consider risks they bring in. Looking at the Figure 7 and Figure 8, however, now from the perspective of China, it is understandable why OBOR Initiative fosters mechanisms such as $16+1$ targeting a market of over 120 million, out of which $85 \%$ is in the EU. CEES market is an ideal host to megaprojects promoted by OBOR Initiative, as their completion narrows down the industrial and economic development gap between the CEEC countries and Western European countries.

\section{CONCLUSION}

OBOR Initiative is a unilateral funding infrastructure portfolio of megaprojects spanning on three continents, a part of a lasting national economic progress plan, and as such carries considerable risks. Magnitude of megaprojects is comparable to the magnitude of potential damage to stakeholders in case of project failure. Main risks concern nonperforming loans (NPL) and low quality. The NPL risk lies in the simplified structure of unilateral credit loan financing provided by Chinese authorities and the fact that credit loan contracts can be signed with potentially underperforming clients. In this case, the lender is vulnerable to the option of the credit loan going default. The issue of low quality lies on one hand in high conformity required by European markets in terms of developing megaprojects, but also on the other hand in Chinese approach of subcontracting at dumping prices, originating from the Chinese national concept of wanting to export its goods and labor.

LFA and LFM can contribute to OBOR Initiative megaprojects' efficiency by anticipating key risks in the preliminary development stages. LFA and LFM account for a multitude of different mutually independent parameters that inevitably occur in developing megaprojects, such as issues related to overcoming cultural differences, political instability, wars, natural disasters, disputes that arise from religious or ethnical backgrounds, which will jeopardize sustainability of OBOR Initiative megaprojects. Moreover, LFA with LFM can be used as a reliable planning tool for interpreting complex yet progressive economic development of China in the past and upcoming period (Figure 10). Finally, the intervention logic of
LFM, conclusive with the Chinese national approach of Mr. Deng Xiaoping, clearly indicates peace being the key prerequisite for economic prosperity. China is without a doubt decisive in accomplishing its Quianmian Xiaokang goal, and will not jeopardize it by contributing to any war or war-related situations. This provides valuable comfort to all OBOR Initiative sceptics who interpret it as a geopolitical hostile takeover mechanism.

\section{LITERATURE}

Shen, S., \& Chan, W. (2018). A comparative study of the Belt and Road Initiative and the Marshall plan. Palgrave Communications, 4(1), 32 .

Schmidt, T. (2009). Strategic project management made simple: Practical tools for leaders and teams. John Wiley \& Sons.

Brookes, N. J., \& Locatelli, G. (2015). Power plants as megaprojects: Using empirics to shape policy, planning, and construction management. Utilities Policy, 36, 57-66.

Hu, Y., Chan, A. P., Le, Y., \& Jin, R. Z. (2013). From construction megaproject management to complex project management: Bibliographic analysis. Journal of management in engineering, 31(4), 04014052.

Locatelli, G., Mancini, M., \& Romano, E. (2014). Systems engineering to improve the governance in complex project environments. International Journal of Project Management, 32(8), 1395-1410.

Locatelli, G., Mikic, M., Kovacevic, M., Brookes, N., \& Ivanisevic, N. (2017). The successful delivery of megaprojects: a novel research method. Project Management Journal, 48(5), 78-94.

Merrow, E. W. (2011). Industrial megaprojects: concepts, strategies, and practices for success (Vol. 8). Hoboken, NJ: Wiley.

Kardes, I., Ozturk, A., Cavusgil, S. T., \& Cavusgil, E. (2013). Managing global megaprojects: Complexity and risk management. International Business Review, 22(6), 905-917.

Geraldi, J., Maylor, H., \& Williams, T. (2011). Now, let's make it really complex (complicated) A systematic review of the complexities of projects. International Journal of Operations \& Production Management, 31(9), 966-990.

Pich, M. T., Loch, C. H., \& Meyer, A. D. (2002). On uncertainty, ambiguity, and complexity in project management. Management science, 48(8), 1008-1023.

Howell, D., Windahl, C., \& Seidel, R. (2010). A project contingency framework based on uncertainty and its consequences. International Journal of Project Management, 28(3), 256-264.

Shenhar, A. J., \& Dvir, D. (2007). Reinventing project management: the diamond approach to successful growth and innovation. Harvard Business Review Press. 
Pennings, J. M. (1992). Structural contingency theory-a reappraisal. Research in organizational behavior, 14, $267-$ 309.

Douma, S. W., \& Schreuder, H. (2008). Economic approaches to organizations. Pearson Education.

Luzzini, D., Caniato, F., Ronchi, S., \& Spina, G. (2012). A transaction costs approach to purchasing portfolio management. International Journal of Operations \& Production Management, 32(9), 1015-1042.

Flyvbjerg, B. (2017). Introduction: The iron law of megaproject management.

Van de Graaf, T., \& Sovacool, B. K. (2014). Thinking big: Politics, progress, and security in the management of Asian and European energy megaprojects. Energy Policy, 74, 16-27.
Sovacool, B. K., \& Cooper, C. J. (2013). The governance of energy megaprojects: politics, hubris and energy security. Edward Elgar Publishing.

World Bank, United States Census Bureau

OECD National Accounts data files

Eisenhardt, K. M. (1989). Building theories from case study research. Academy of management review, 14(4), 532-550.

Farnell, J., \& Crookes, P. I. (2016). Conclusion: Optimism or Pessimism about the future of EU-China Economic Relations?. In The Politics of EU-China Economic Relations (pp. 217-232). Palgrave Macmillan, London

Markovic, D. S., Zivkovic, D., Cvetkovic, D., \& Popovic, R. (2012). Impact of nanotechnology advances in ICT on sustainability and energy efficiency. Renewable and Sustainable Energy Reviews, 16(5), 2966-2972. 